UDC 316.42:1/14:342:32

Jacek ZALESNY,

Vitaliy GONCHAROV,

Marina SAVCHENKO

\title{
MODEL OF THE EVOLUTION OF SOCIAL DEVELOPMENT IN THE PHILOSOPHY OF GLOBAL CONSTITUTIONALISM
}

\begin{abstract}
This article is devoted to the conceptual analysis of the model of the evolution of social development in the philosophy of global constitutionalism.

Purpose of the research: to develop and justify the model evolution of social development within the framework of the social concept of global constitutionalism.

The object of research: the phenomenon of globalisation of socio-political, state-legal and financialeconomic development of national societies and states as an appearance of social reality, highlighted in the social concept of global constitutionalism.

The subject of research: theoretical content and stages of development of the model of the evolution of social development in the philosophy of global constitutionalism concerning its social essence.
\end{abstract}

Keywords: global constitutionalism, model, evolution, social development, philosophy, social concept, features, global goal, organisational nature, political sphere.

Introduction

The research questions of concepts of social development in the philosophy of modern interpretations of social reality in the context of globalisation are studied extensively in the works of Amin S. (2007), Appadurai A. (1990, pp. 295310; 1996, pp. 178-199), Arrighi G. (2008, pp. 57-72), Bauman Z. (1998), Beck U. (1998, pp. 28-31; 2000), Wallerstein I. (2001), Weber M. (2006), Giddens E. (1990, p. 64), dos Santos T. (1972, pp. 7-12), Kagan R. (1996), Comte A. (2011 ${ }^{\text {a }}$, Kristol I. (1995, p. 37), Lash S. and Urry J. (2002), Næss A. (1948; 1989), Robertson R. (1995, pp. 25-42), Sklair L. (1991, p. 7), Therborn G. (1995, pp. 738-739), and some other au- thors.

These works form the basis for the formulation of the main features of the model of the evolution of social development in the philosophy of global constitutionalism.

However, the share of studies covering the issues of elaboration and justification of the evolution of social development in the framework of the main socio-philosophical approaches to ensure the comprehensive development of national societies and States, provided that a balance of international (global) and national (state) interests in all spheres of their life in connection with the systematic expansion of Western interpretations of the social system is extremely small.

In this regard, the primary purpose of this 
study is to develop and substantiate the evolution of social development within the framework of the social concept of global constitutionalism, and the subject of the study is the theoretical content and stages of development of the model of the evolution of social development in the philosophy of global constitutionalism in relation to its social essence.

The model of the evolution of the social development in any social conception involves the development and justification of its own design of formation and development of the society. Most of the social teachings of our time, embodied in the practice of state-political construction of certain states and societies, justifying the constructive features of the evolution of the social development, are based on the achieved within the existing national states and societies level of society-political, state-legal and financialeconomic development, as well as a variety of experience of socio-philosophical description of models of the world.

Global constitutionalism as a social concept functions as a socially determined and tendentiously aberrative form of perception and explanation of reality, being a knowledge system of a socio-philosophical and politico-legal nature, based on fundamental universal democratic values regarding the need to organise interstate, state and public life on a global scale at accordance with the ideological basis of the modern stage of development of capitalism in the world.

The philosophy of global constitutionalism, which was finally formed at the turn of the 20th and 21 st centuries as an active tool for formatting society-political, state-legal, financial and economic development of modern national States in the hands of the global governing class, is based on the experience of social concepts of the past, especially neoliberal and neoconservative doctrines.

In this regard, the model of the evolution of social development constructed within the framework of the concept of global constitutionalism is characterised by several features.

First, it is progressive, that is, it is based on the understanding of the future borrowed from liberalism and neoliberalism as continuous progress in the development of humankind. At the same time, progress is the main goal and motivation of any activity carried out in society. So, B. V. Vasilyev (2005) notes that the "neoliberal "formula of progress" was expressed in the understanding of the comprehensive development of the personality as the goal of the progress of society and public organisation as a means to achieve this goal. The neoliberal paradigm of social progress included the idea of the relationship between liberalism and democracy" (pp. 515). However, in the context of global constitutionalism, the progressive orientation of the model of the evolution of social development is corrected towards the controllability and manipulated nature of social-political, state-legal, financial and economic development of national states by the global governing class.

Meanwhile, the global governing elite, as noted by A. Posadsky (2016): "The classical understanding of rationality and scientific and technical progress cause distrust. They seek to freeze the existing order of things, rejecting the very possibility of creative breakthroughs. They see the improvement of technological systems and classical scientific knowledge as a threat to the "ecological" and "economic" humanity, which has clear limits of development" (p. 1). Thus, the philosophy of global constitutionalism is selec- 
tive to the possibilities of progressive development of society, considering progress only as a process of creating the necessary tools for the active manipulation of social processes, forcing them to the general logic of the development of the world capitalist system and the preservation of power and property by the ruling elites, which by the end of the 20th century formed a single global governing elite. In this case, A. Posadsky (2016) points to the repressive nature of progressivism in the context of globalisation: "Neoliberal ... "therapy" of human nature opens the way for a triumphal procession of unconscious archaic impulses and drives. They are based on the description of the transformation of human instincts as their "repressive suppression". All this, in turn, turns into the encouragement of conformist attitude to reality, egoistic adaptation to it. Humanity, bound by natural-unconscious bonds, is closed in an infantile "paradise". Here the creative potency of the individual, the desire for the actualisation of spiritual meanings, for a constructive transformation of social conditions become unclaimed" (pp. 1-3).

Secondly, it carries out the sacralisation and mythologisation of democratic values and rights as public institutions of modern state-organised society. At the same time, a kind of cult of democratic values and legal institutions in the philosophy of global constitutionalism is quite twofaced. On the one hand, the universal access of humankind to democratic values and legal protection concluded in the norms and principles of international law, as well as in national legal systems integrated into a single global legal system, is declared. Nevertheless, on the other hand, in practice, access to the institutions of democracy, as well as mechanisms of the legal protection of the rights, freedoms and legitimate interests of man and citizen, is everywhere conditioned by the citizenship and material status of man, his belonging to the global governing class.

So, P. A. Shashkin (2016) said: "This... understanding of human rights ... has already become a kind of "Bible" of globalism - a project aimed at seizing power and imposing "humanistic" values on all humankind as universal. There is a kind of substitution of concepts. Representative democracy in the modern world is often replaced by the power of bureaucracy (a clear illustration is the apparent weakness of the representative bodies of the EU against the background of the omnipotence of the Brussels bureaucratic machine), the constitutional state- by the right of the strong (or, something the same, rich), the equality of all forms of ownership- by the actual dominance of private property and the cult of privatisation" (p. 1). The aim of this global project is, in fact, to build an uncontrolled oligarchic transnational power that rejects any and all national traditions and identities, if they somehow do not fit into the new world order.

Third, the philosophy of global constitutionalism has a pronounced Darwinian character. At the same time, some authors notes the global evolutionism of this philosophical doctrine, which focuses on identifying directions, trends and patterns of only the continuous progressive development of all things are available to modern science, which are invariant and can claim to explain the emergence of humanity and predict its further interaction with the nature of the Earth and space: "This type of evolutionism began to play an important role as a paradigm integrator of scientific knowledge, an active conductor of evolutionary views in science, especially in the formation of new areas of scientific research" (Ursul, A. D. \& Ursul T. A., 2016).

The social-Darwinian character of global constitutionalism, on the one hand, is based on 
the linearity of the development of human society, justifying its universality, which generates globalisation processes. On the other hand, the declared equality of states and peoples serves as a justification for the legitimacy of ignoring the particularities of individual nations and states for the benefit of the realisation of universal progressive development.

That is, the global constitutionalism with all the declared equality carries such social-darwinist moments as the priority of the West over the rest of the world; the priority of the Western picture of the social development over the models of the social development, substantiated within the framework of non-Western socio-philosophical concepts; the violent planting of mythical democratic values on a planetary scale; the sacralisation of the Western way of life and worldview concept.

Fourthly, the philosophy of global constitutionalism borrows from neoconservative models the conceptual provisions regarding "the inequality of peoples, socio-political classes, individual countries, etc." (Kagan, 1996; Kristol, 1995, p. 37).

At the same time, several philosophers note that some principles of global constitutionalism directly violate human rights, for example: "the existing world consists of individuals and corporations driven by their private interests, so society is just a simple set of selfish interests and the rights of human communities are not protected; economic growth requires "creative destruction" in which "inefficient" activities are allowed to die, giving way to successful enterprises using advanced technologies" (Shashkin, 2016).

Fifth, the model of the evolution of social development in the philosophy of global constitutionalism in fact acts as an involutional structure of world development. And not only in terms of spiritual involution (justification of sexual perversions, social Darwinism, violence, sanctions, religious perversions, etc.) but also in terms of material and technical involution (despite the declared transition to the sixth technological mode). At the same time, the media, Western cinema complement involutional component of Western globalisation of sociopolitical, state-legal and financial-economic structure of national states by the apocalyptic vision of the future development of mankind. However, it is impossible to consider that foresight of apocalyptic character of the future is inherent only in the supporter of the concept of global constitutionalism.

A number of thinkers, philosophers and religious figures (for example, Patriarch Kirill) note that the involutional nature of the processes of globalisation of the Western model and the blurring of the boundaries of good and evil, inevitably lead humanity to the risk of an apocalyptic end in development (Patriarch Kirill, 2016). Despite the pessimistic forecasts of social development in the framework of the model of the evolution of social development in the concept of global constitutionalism, its authors deny the possibility of revising the basic principles of this doctrine concerning the freedom of the market, the exaltation of democratic values and human rights, the legal system, etc.

Moreover, according to some authors, global constitutionalism considers "spontaneously composing market and natural orders as perfect in comparison with rationally and artificially created ones. Interference in their environment, improvement and creative change are declared unacceptable. Thereby, the ways of the creative perfection of the social development, the modernisation movement of society, scientific and technological development in combination with 
the moral perfection overlap ... "more perfect" natural orders can always be "cleaned" of such "too human" and "polluting" world factors as creative freely believing personality, people's states and economies, institutions of morality, science and culture" (Posadsky, 2016).

Sixth, the philosophy of global constitutionalism contains elements of neoliberal environmentalism (Næss, 1948; 1989), in which man cannot be considered as a sovereign individual, a free creator of his history. A man as a person is split in anonymous realities, his comfort is provided by depersonalisation of the processes of social development. At the same time, such a touching "concern for the environment", which is demonstrated by the neoliberal and neoconservative circles of the West, in fact, pursues the goal of subordinating social development to the technologies of social construction controlling by the ruling classes, eliminating the creative human principle in it. At the same time, due to the fact that the "decoding" of the processes of the unconscious "monopolisation" within the framework of Western neoliberal philosophical doctrines, the processes of development and material and social being that do not meet the interests of the global governing class are defamed as a social pathology. As a result, any progress in the development of mankind that gives a person the opportunity of creative, cultural, moral and moral development, and not degradation, since the second half of the 20th century (and, especially, since the 21st century) is blocked. The West is organising the real terror against States and societies that impede this process.

Various models of the evolution of social development in the context of globalisation of socio-political, state-legal and financial-economic development of existing national States and societies, actively studied by modern philoso- phers, lawyers and political scientists, play a significant role in the formation of the model of the evolution of social development within the framework of global constitutionalism (Ivanov 2016).

These include, in particular, models: linear global studies (Comte, 2011); the world-system globalisation (I. Wallerstein, A. G. Frank, S. Amin, G. Arrighi, T. dos Santos, A. I. Fursov, A. V. Karataev) (Wallerstein, 2001; Amin, 2007; Frank \& Gills, 1996; Arrighi, 2008, pp. 57-72; dos Santos, 1972; Fursov, 2008, pp. 255-304); globalisation as a continuation of modernisation (Giddens, 1990); global system (Sklair, 1991, p. 7); global sociality (U. Beck, G. Terborn) (Ternborn, 1995, pp. 738-739; Beck, 1998, pp. 28-31); "weak" States (Bauman, 1998); disorganised capitalism (Lash \& Urry, 2002); globolocalisation (R. Robertson, M. Archer, N. Smelser, etc.) (Robertson, 1995, pp. 25-42); world risk society (Beck, 2000); deterritorialisation (Appadurai, 1996, pp. 295-310).

In particular, within the framework of the model of linear globalism, the evolution of the social development is a gradual integration of the world through the processes of unification, universalisation, integration of socio-political, statelegal and financial-economic structure of individual national states and societies. At the same time, the paradigm of the linear process does not imply a revolutionary change of internal principles and quality of globalisation processes in the globalisation. The world community, gradually integrating, extensively neutralises the contradictions existing in national societies and States, which, according to this model of the evolution of social development, are a consequence of the differences in their structure.

According to this model, globalisation, in any case, acts as a common good, having a use- 
ful, rational and progressive nature, and any opposition to the processes of globalisation is considered as an anti-human act that requires censure and negative social impact. In part, this model in the era of O. Comte $\left(2011^{\mathrm{b}}\right)$ and later, until the second half of the 20th century, had a good reason, as its progressive nature was evident: under the pressure of integration processes and popularisation of general democratic values, human rights and freedoms, the world colonial system was broken, slavery was abolished everywhere, the population of most countries began to be fixed in the fundamental laws (constitutions) of all kinds of political, economic, social and inalienable rights and freedoms of man and citizen. This significantly raised the socioeconomic standard of living of the population, increased the expectancy and quality of life, changed the moral, cultural and ethical image of the average citizen of the Western countries.

However, later, since the second half of the 20th century, the linear model of globalisation, which does not take into account the national, cultural, socio-economic and other features of certain national societies and States, as well as the adverse socio-economic consequences of globalisation processes in the countries of the periphery of the world capitalist system, has ceased to respond to objective reality. It could not be used in full within the framework of the concept of global constitutionalism, except for its individual elements (for example, in terms of levelling the contradictions existing in national societies and States).

Within the framework of the world-system globalisation model, the evolution of social development is a consistent evolution of various sets of world-systems. So, I. Wallerstein (2001) divides them into several types: "mini-systems (which were inherent in the primitive communal system); world-economy (society, acting in the form of evolving systems, but not United in a single political system); world-Empire (worldeconomy, evolved by combining under the authority of one state in complex systems); modern world-system (emerged by the evolution of the medieval European world-economy)" (pp. 1015).

It seems that this model of the evolution of social development has a particular value in the study of globalisation, as it explores the social evolution of the systems of societies, not individual societies. However, within the framework of this model, there are no clearly defined fundamental laws underlying the essence of the social development (in this part, the world-system analysis uses the theoretical basis developed within the framework of Marxist doctrine), it does not contain the formulation of the fundamental basis of globalisation processes, and also rather vaguely defines the properties of globalisation as a natural process of evolution of sociopolitical, state-legal and financial-economic development of national states and societies.

The model of globalisation as a continuation of the modernisation of E. Giddens (1990) defined the evolution of social development in the framework of the processes of globalisation as follows: "As an intensification of social relations extending to the whole world (worldwide), which connect remote places (localities) in such a way that local events are formed by events occurring many miles away from them, and vice versa, ... and globalisation....as a direct continuation of modernisation, which consists in the autonomy of social relations from the local conditions of interactions, to the spread of the action of decontextualising institutions to the whole world, believing that modernity is inherent in globalisation" (pp. 63, 64). 
Consideration of the model of the evolution of social development through the prism of modernisation processes, widespread in the planetary scale, is although somewhat idealised, but allows us to explore globalisation as a systematic process of qualitative changes in all parameters of the organisation and functioning of society at the state and international level. At the same time, the Giddens (1990) model contains several institutional dimensions in which the modern societypolitical system is formed: "this is actually the modern world economy, the system of national States; the international division of labour; the world military order" (p. 71). Although in fact, only two generalised institutional dimensions are used - the world economy and politics. It has several features in common with the worldsystem model of I. Wallerstein, however, in contrast, considers both levels of systemic connections (local and global), in which the transformation of the social system is carried out within the framework of globalisation. At the same time, global linear trends and localised phenomena of everyday life of society interact.

However, A. Giddens, exploring in his model of the processes of globalisation as a complex two-tiered process of transformation of the social system, does not analyse the economic mechanism, which allows in the framework of the world capitalist system to carry out its balancing and stabilisation due to the export of costs from the West to the states of peripheral capitalism.

In the framework of the model of the global system of L. Sklair globalisation acts as an evolutionary process of forming a system of transnational practices autonomised from conditions within national States and national-state interests in international relations.

Transnational practices are implemented at three levels: economic (TNC); political (at the same time a capitalist class is being formed on a planetary scale); ideological and cultural, generating consumerism (Sklair, 1991, p. 7). Thus, the model of the global system of L. Sklair defines the evolution of the social development of the era of globalisation as the gradual formation of a system of transnational capitalism, sweeping and levelling national borders. At the same time, this model recognises the existence of an extensive system of supranational actors that initiate the processes of globalisation of socio-political, state-legal, financial and economic life in individual national States, as well as control over their course, in the interests of the global governing class. This model defines as the main properties of globalisation as the process of evolution of the social development the formation of global free markets and liberal economic relations (collectively forming the world capitalist system).

However, revealing the organisational nature of the initiation of globalisation processes, this model contains a somewhat archaic definition of the actors and beneficiaries of globalisation processes, which are the global governing elite represented by the global governing class at the international and national-state levels.

In the framework of the model of global sociality (U. Beck and G. Therborn) globalisation is seen as a transnational social space, "unbounded daily activities in various dimensions of economy, information, ecology, technics, transcultural conflicts and civil society..." (Beck, 1998, p. 44). At the same time, within the framework of this model, the processes of globalisation in the socio-political, state-legal, financial and economic life in individual national states, although they have a common nature and the actors that initialise them, however, proceed according to their own logic of development, not reduced one to 
another.

At the same time, in the political sphere, globalisation involves the gradual levelling of state sovereignty through the influence of transnational actors, creating specific organisational and legal networks both within States and at the international level; in the economy, globalisation is embodied in the form of denationalisation and disorganisation of transnational capital, finally going beyond national legal regulation and controlling international financial and commodity flows; in the socio-cultural sphere, globalisation is characterised by the interpenetration of local cultures in transnational spaces, which are the world's largest megacities of developed States, as well as their capitals (Beck, 1998, pp. 28, 40, 42, 131).

Model of globolocalisation (R. Robertson, M. Archer, N. Smelser, etc.) (Robertson, 1995, pp. 25-42), weak States Z. Bauman (1998), disorganised capitalism S. Lash and J. Urri (2002) also contains a thesis about the existence of its own logic of globalisation processes in the sociopolitical, state-legal, financial and economic life of individual national States, and at the international level, with the primary goal of globalisation processes is to preserve and develop the existing world capitalist system. In this regard, U. Beck (2000) attempts to build his model of globalisation (model of the world risk society Weltrisikogesellschaft), based on the processes in the field of ecology, adapting the previously developed theory of risk society to the analysis of globalisation processes; at the same time, within the framework of the model of the world risk society, the processes of globalisation are considered separately at the global and local levels in the economy, politics, culture, morality, etc. (pp. 10-17).

The study of the model of deterritorialisa tion developed by A. Appadurai (1996) has great importance in understanding the model of the evolution of social development within the framework of the philosophy of global constitutionalism (pp. 178-199). Within the framework of this model, firstly, the opposition of the worldsystem analysis of the theory of globalisation is carried out; secondly, globalisation is considered as a process of gradual loss of binding of social processes to the territorial space; thirdly, A. Appadurai (1990) justified the position that local cultural and symbolic space-flows (ideological, consisting in the processes of perception by some ideologists, developed by others; ethnic, formed by migration and tourist flows; technical, consisting in the import-export of technologies; financial, formed by the movement of capital; media, consisting in the movement of flows of images) form a global cultural flow, and the interaction of people is symbolic (pp. 296, 301).

The model of deterritorialisation quite rightly notes that within the framework of globalisation, the formation of a global cultural flow is carried out, in which the transfer of state-legal, social and political institutions, principles, relations, relations, ideas is carried out in a symbolic form, but A. Appadurai does not indicate the fact that this transfer occurs, as a rule, unilaterally (from the countries of the core of the capitalist system to the countries of its periphery), and as methods of transmission is the imposition by military-political, financial-economic, culturalcreative and information expansion of the West on a planetary scale.

Thus, the model of the evolution of the social development within the framework of the philosophy of global constitutionalism defines globalisation as an objective process of development of socio-political, state-legal, financial and economic life of individual national States 
on a planetary scale following the ideological basis of the modern stage of development of capitalism in the world. This ideological basis consists in the violent (expansionist) transfer of state-legal, socio-political institutions, principles, relations, ideas from the West to the rest of the world.

The global goal of the evolution of the social development in the philosophy of global constitutionalism is to ensure the functioning and development of the world capitalist system by exporting costs from its centre (core) to the countries of the periphery, as the most favorable socio-economic form, allowing to maintain power and property in the hands of the global governing elite in the face of the global governing class.

\section{Conclusions}

Social concept global constitutionalism basic on fundamental universal democratic values regarding the need to organise interstate, state and public life on a global scale at accordance with the ideological basis of the modern stage of development of capitalism in the world.

The model of the evolution of social development in the philosophy of global constitutionalism is defined as a structure of formation and development of the society, which has a progressive, pronounced Darwinist character, carrying out the sacralisation and mythologisation of democratic values and law as public institutions of modern state-organised society, borrowing from neoconservative models conceptual provisions concerning inequality of peoples, sociopolitical classes, individual countries, in fact serving in the involutional structure of the world development containing elements of neoliberal environmentalism.

\section{REFERENCES}

Amin, S. (2007). Virus liberalizma. Permanentnaya vojna $i$ amerikanizaciya mira (The Virus of Liberalism. Permanent War and Americanisation of the World, in Russian). Moscow: Europe.

Appadurai, A. (1990). Disjuncture and Difference in the Global Cultural Economy. Theory, Culture \& Society, 7, 295-310.

Appadurai, A. (1996). Modernity at Large: Cultural Dimensions of Globalisation. Minneapolis; London: University of Minnesota Press.

Arrighi, G. (2008). Globalizaciya i istoricheskaya makrosociologiya (Globalisation and Historical Macro-Sociology, in Russian). Prognosis 2, 57-72.

Bauman, Z. (1998). Globalisation: The Human Consequences. Cambridge: Cambridge University Press.

Beck, U. (1998). Was ist Globalisierung? Frankfurt/M.: Suhrkamp.

Beck, U. (2000). Risk Society: Towards another Modern. Moscow: Progress-Tradition.

Comte, A. $\left(2011^{\mathrm{a}}\right)$. Overview of Positivism. Moscow: Book House "LIBROKOM".

Comte, A. $\left(2011^{\mathrm{b}}\right)$. The Spirit of Positive Philosophy: A Word about Positive Thinking. 2nd. ed. Moscow: Book House "LIBROKOM".

Dos Santos, T. (1972). Socialismo o Fascismo. El Nuevo Caracter de la Dependencia y el Dilema Latinoamericano. Santiago de Chile: Prensa Latinoamericana.

Frank, A. G. \& Gills, B. K. (1996). The World System: Five Hundred Years or Five Thousand? London: Routledge.

Fursov, A. I. (2008). Mir, kotoryi my pokidaem, 
mir, v kotoryi my vstupaem, i mir mezhdu nimi (Kapital(izm) i Modern - skhvatka skeletov nad propast'yu?) (The World we are Leaving, the World we are Entering, and the World between them (Capital (ISM) and Modern - the Battle of Skeletons over the Precipice?, in Russian). In D. A. Andreev \& V. B. Prozorov (Eds.), De Futuro, or the Story of the Future (pp. 255-304). Moscow: Political Class.

Giddens, A. (1990). The Consequences of Modernity. Stanford: Stanford University Press.

Ivanov, D. V. (2016). Evolyuciya koncepcij globalizacii (Evolution of the Concepts of Globalisation, in Russian). VALS. Retrieved November 10, 2019 from: http://vals.narod.ru/glob/gl_ivanov1.ht $\mathrm{m}$.

Kagan, R. (1996). Toward a Neo-Reaganite Foreign Policy. CARNEGIEENDOWMENT. Retrieved November 10, 2019 from: $\quad$ https://carnegieendowment. org/publications/index.cfm?fa=view\&i $\underline{\mathrm{d}=276}$.

Kristol, I. (1995). Neoconservatism: The Autobiography of an Idea. New York: The Free Press.

Lash, S., \& Urry, J. (2002). Economies of Signs and Space. London: Sage Publications. doi:10.4135/9781446280539.

Næss, A. (1948). Interpretation and Preciseness. II. Mimeographed. Oslo.

Næss, A. (1989). Ecology, Community, and Lifestyle. Cambridge: Cambridge University Press.

Patriarch Kirill. (2016). Vystuplenie Svyateishego Patriarkha Kirilla v Kievo-Pecherskoi Lavre na vstreche s episkopami, dukho- venstvom, monakhami, miryanami, prepodavatelyami i studentami Kievskoi Duhovnoi Akademii (Speech of His Holiness Patriarch Kirill at the KievPechersk Lavra at the Meeting with Bishops, Clergy, Monks, Laity, Teachers and Students of the Kiev Theological Academy, in Russian). PATRIARCHIA. Retrieved August 10, 2019 from:

http://www.patriarchia.ru/db/text/70727 4.html.

Posadsky, A. (2016). Neoliberalizm i ekologizm. Podrobnye Tezisy (Neoliberalism and Ecologism. Detailed Abstracts, in Russian). The Conciliar Hearings of the World Russian National Cathedral on the Topic "Economy in the Context of Globalisation. National View". Retrieved November 10, 2019 from: http://www.vrns.ru/analytics/4197/\#.V7 sxs49OLIU.

Robertson, R. (1995). Glocalisation: Time-Space and Homogeneity- Heterogeneity. In M. Featherstone, S. Lash, \& R. Robertson (Eds.), Global Modernities (pp. 2542). London: Sage Publications. doi:10.4135/9781446250563.n2.

Shashkin, P. A. (2016). Suverennaya demokratiya $v$ konturakh novogo mirovogo poryadka. Khristianskii vzglyad na sovremennye problemy social'no-ekonomicheskogo razvitiya (Sovereign Democracy in the contours of a New World Order. Christian View on Contemporary Problems of Socio-Economic Development, in Russian). PERSPEKTIVY. Retrieved November 10, 2019 from: http://www.perspektivy.info/ print.php?ID=35961. 
Sklair, L. (1991). Sociology of the Global System. Hemel Hempstead: Harvester Wheatsheaf.

Therborn, G. (1995). European Modernity and Beyond: The Trajectory of European Societies 1945-2000. London, New Delhi: Sage Publications.

Ursul, A. D., \& Ursul, T. A. (2016). Ideya evolyucii i global'nogo evolyucionizma (The Idea of Evolution and Global Evolutionism, in Russian). SOCIONAUKI. Retrieved November 10, 2019 from: http://www.socionauki.ru/news/158140

Vasilyev, B. V. (2005). Filosofiya prava russkogo neoliberalizma konca XIX-nacha- la XX veka (Philosophy of Law of the Russian Neo-Liberalism in the Late XIX - Early XX Century, in Russian). (Doctoral Dissertation, Saint Petersburg).

Wallerstein, I. (2001). Analiz mirovykh sistem $i$ situacii $v$ sovremennom mire (Analysis of World Systems and the Situation in the Modern World, in Russian). SaintPetersburg: University book.

Weber, M. (2006). Protestantskaya etika i dukh kapitalizma (Protestant Ethics and the Spirit of Capitalism, in Russian). Moscow: Russian Political Encyclopedia. 